\title{
HATÁR MENTI EGYÜTTMÜKÖDÉSI LEHETŐSÉGEK A KÖZFORGALMÚ KÖZLEKEDÉSBEN
}

\section{Cross-border cooperation opportunities in public transport}

$$
\text { Lévai Zsolt }{ }^{1} \text { - Munkácsy András }{ }^{2} \text { - Schváb Zoltán }{ }^{3}
$$

\begin{abstract}
Absztrakt: Az európai integráció megnyitotta az egyes országok határait, ami gazdasági-társadalmi együttmúködést eredményezett az egyes határ menti régiók között. Az új kapcsolatokat ugyanakkor a közlekedés nem minden esetben követte le. A határok átjárhatósága ellenére az egyes közforgalmú közlekedési rendszerek továbbra is csak adott országban voltak elérhetők. A fejlődés azonban kikényszerítette a hiányzó kapcsolatok pótlását, a közforgalmú közlekedési rendszerek összekapcsolását. Milyen európai jó példákat találunk erre, és milyen lehetőségeket látunk Magyarország tekintetében a határ menti közforgalmú együttműködésekre? Tanulmányukban kutatási eredményeink szintézisét tesszük közzé.
\end{abstract}

Kulcsszavak: határon átnyúló közlekedés, regionális tervezés, közlekedési szövetség, együttmúködés a közlekedésben, közforgalmú közlekedés

\footnotetext{
${ }^{1}$ Lévai Zsolt, okl. közlekedésmérnök, a KTI Közlekedéstudományi Intézet Nonprofit Kft. (a továbbiakban: KTI) Közlekedésfejlesztési Kutatóközpont szenior kutatója, a Széchenyi István Egyetem ÉÉKK Közlekedési Tanszék oktatója, a Nemzeti Közszolgálati Egyetem HHK Katonai Műszaki Doktori Iskola doktorandusza. E-mail címe: levai.zsolt@,kti.hu A szerző további munkásságát lásd a Magyar Tudományos Művek Tárában: https: $/ / \mathrm{m} 2 . \mathrm{mtmt} \cdot$ hu $/$ gui2 $/$ ?type $=$ authors\&mode $=$ browse\&sel $=10067548$

2 Dr. Munkácsy András, PhD (közlekedés- és járműtudományok), okl. közgazdász, a KTI tudományos főmunkatársa, a Közlekedésfejlesztési Kutatóközpont vezetóje. E-mail címe: munkacsy.andras@,kti.hu

A szerző további munkásságát lásd a Magyar Tudományos Művek Tárában: https: / / m2.mtmt.hu/gui2/?type=authors\&mode=browse\&sel $=10061167$

${ }^{3}$ Schváb Zoltán, okl. építőmérnök, okl. közlekedésépítő szakmérnök, a KTI ügyvezetője. A BME Vasúti Járművek és Járműrendszeranalízis Tanszék óraadója, a Magyar Igazságügyi Szakértői Kamara elnöke, az MKIK Teljesítésigazolási Szakértői Szerv vezetőhelyettese. Email címe: schvab.zoltan@,kti.hu.
}

A szerző további munkásságát lásd a Magyar Tudományos Művek Tárában: https: $/ / \mathrm{m} 2 . \mathrm{mtmt}$. hu $/$ gui2 $/$ ?type $=$ authors\&mode=browse\&sel $=10050063$ 
Abstract: European integration has opened up state borders, leading to socio-economic cooperation between border regions. However, the new links have not always been matched by transport. Despite the interoperability of borders, each public transport system was still accessible only in its own country. Nevertheless, development has forced the missing links to be filled in and public transport systems to be interconnected. What good examples may be found in Europe and what opportunities for crossborder public transport cooperation may be seen in Hungary? In this study, a synthesis of our previous research outcomes are summarized.

Keywords: cross-border transport, regional planning, transport association, transport cooperation, public transport

\section{BEVEZETÉS}

Az Európai Unióhoz (a továbbiakban rövidítve: EU) történő csatlakozás új lehetőséget kínált a szomszédos országok közötti kapcsolatok javitására, fejlesztésére. ${ }^{4}$ Az európai integráció többek között a személyek és áruk szabad áramlását indította el Magyarország vonatkozásában is. ${ }^{5} \mathrm{Az}$ EU Alapjogi Chartája ${ }^{6}$ megnyitotta a lehetőséget a külföldi utazások előtt is, amely a schengeni csatlakozással vált teljessé. A mozgási szabadság és a külföldi lehetőségek a munkaerőpiacon is éreztették hatásukat. A kedvezőbb lehetőségek hatására a határ menti térségekből sokan a határ túloldalán adódó munkalehetőségeket választották, és napi rendszerességgel járnak át dolgozni, számuk folyamatosan növekszik. ${ }^{7}$ A határok átjárhatósága azonban nemcsak a munkaerőpiacon fejtette ki hatásait, hanem a társadalmi-gazdasági élet számtalan területén a határ menti régiók kapcsolódását is elhozta. Az oktatás, az egyes vállalkozások együttmúködése, a kultúra sokszínűsége, kisebb részben a politika alakulása ${ }^{8}$ mind-mind hatással volt a szomszédos határ menti régiók egymás közötti mobilitására. Magyarország esetében a mobilitás további ösztönzője volt a családi-

\footnotetext{
${ }^{4}$ FEJES, 2010.

5 1993. január 1-jével létrejött az egységes piac, amely megvalósította a négy alapszabadság, az áruk, a szolgáltatások, a személyek és a tőke szabad áramlását (EU, é. n.).

${ }^{6} \mathrm{EU}, 2012$.

${ }^{7}$ KOVÁCS - SIPOS, 2020.

${ }^{8}$ KRUPPA, 2003.
} 
rokonsági kapcsolatok megléte is. A rokonlátogatás könnyebbsége megnövelte a közlekedési igényeket a szomszédos országokkal.

A fentiek jelentős hatással voltak a közlekedési rendszerre. A határ menti regionális kapcsolatok erősödése közlekedési igényeket gerjesztett, amelyeket a rendszer elemeinek kellett kielégítenie. A közúti és vasúti határátkelőhelyeken megnövekedett a forgalom, ugyanakkor a közforgalmú közlekedési rendszerek ezt a növekedést nem követték le, a belföldi járatok csak az országhatárokig közlekedtek, kevés volt a határon átmenő járat. A határ menti régiók közforgalmú közlekedésért felelős szervei nem törekedtek a felmerült mobilitási igények bevonzására, hanem hagyták, hogy az egyéni közlekedés jelentős mértékben megerősödjön a nemzetközi forgalomban. A határon átmenő ingaforgalom fő eszköze a személygépkocsi lett, mert szinte nem is volt más lehetőség a határ túloldalán akár csak pár kilométerre található munkahely vagy más úti cél elérésére. Ez a jelenség több okból is károsnak tekinthető:

- a növekvő közúti forgalom károsanyag-kibocsátása magas, ezzel környezeti károkat okoz;

- a növekvő közúti forgalom hatására a bekövetkező balesetek száma egyaránt nô a szomszédos régiókban is;

- az egyes országok különböző árszínvonala miatt a megtermelt jövedelem elköltése másik országban történik (bevásárlóturizmus).

A közép-európai közlekedési rendszer fejlesztésével foglalkozó CONNECT2 $\mathrm{CE}^{9}$ projekt kutatása megállapította, hogy a vizsgált térségben a személygépkocsi-közlekedés közlekedési munkamegosztásbeli aránya magasabb a nemzetközi, mint a belföldi forgalomban. ${ }^{10}$

Ez a trend arra ösztönözte a határ menti régiókat, hogy kapcsolataikat a közlekedés területén is szorosabbra füzzék. Ennek megfelelően határon átnyúló közforgalmú közlekedési kapcsolatokat alakítottak ki. Korábban inkább csak távolsági nemzetközi közforgalmú közlekedési összeköttetések léteztek, az együttműködés azonban immár a regionális közforgalmú közlekedési kapcsolatok kialakítását eredményezte. Ennek fő szempontjai az alábbiak voltak:

- kínálati harmonizáció;

- finanszírozási kérdések megoldása;

9 CONNECT2CE: Improved rail connections and smart mobility in Central Europe. Interreg Central Europe, 2017-2020. Hazai projektpartnerek: KTI, GYSEV Zrt. www.interreg-central.eu/Content.Node/CONNECT2CE

10 OSZTER, 2020. 
- járművek közlekedési kérdéseinek tisztázása;

- tarifarendszerek kialakítása;

- információ és kommunikáció.

Jelen vizsgálatunk a Közlekedéstudományi Intézet közlekedésfejlesztési múhelyében a 2010-es években - az Európai Unió társfinanszírozásával az országhatárok mentén vagy a tágabb régióban folytatott kutatásaink eredményeit szintetizálja. Kiindulásként feltételezzük, hogy fenti kérdések megoldásával a határon átnyúló helyváltoztatási igények legnagyobb része közforgalmú közlekedéssel kielégíthető. A színvonalas közösségi közlekedés pedig további helyváltoztatásokat indukál a nem mindennapos közlekedés (elsősorban a turizmus) területén is. Számos európai ország határ menti régióiban alakultak ki határon átnyúló közlekedési kapcsolatok, Magyarországon azonban még kevés helyen lehet ilyen közforgalmú járatot találni.

Cikkünkben megvizsgáljuk, hogy a közforgalmú közlekedés terén melyek lehetnek az átjárhatóság akadályai, és elemzünk már működő európai példákat. Vizsgálatunk és korábbi tanulmányaink eredményeinek felhasználásával javaslatot teszünk a magyarországi határon átnyúló közforgalmú közlekedési kapcsolatok rendszerének fejlesztésére.

\section{AZ ORSZÁGHATÁROK SOROMPÓHATÁSA A KÖZLEKEDÉS TERÜLETÉN}

Az országhatárok sok esetben ténylegesen elválasztják a közlekedési rendszereket, akadályozzák a közlekedési kapcsolatokat. Ennek oka, hogy az országok saját elveik és szabályaik alapján építették ki a rendszereiket, amelyek különböztek a szomszédos országétól, így az átjárhatóság nem volt biztosítva. Az alábbiakban ezeket a jelenségeket és a kapcsolódó sorompóhatást mutatjuk be.

\subsection{Eltérő müszaki paraméterek}

A regionális forgalomban leginkább érintett közúti és vasúti közlekedés esetében az előbbi szabályrendszere egységesebb, utóbbié azonban majdnem minden országban más. Nincs ez másként a műszaki paraméterek tekintetében sem. 
A Közúti Közlekedési Egyezmény ${ }^{11}$ révén az aláiró országokban összehangolták a lényeges szabályokat, például az alapvető jelzések egyformák, így többek között a közlekedési lámpák esetében használt színek és az ezekhez társuló jelentés. A kontinensen a forgalmi irányok megegyeznek és csak a brit, a ciprusi és a máltai szigeten kell ellentétes forgalommal számolni. Ez a közút esetében elősegíti az átjárhatóságot, mert a jelzések értelmezése nem különbözik az egyes országokban. Más közlekedéssel kapcsolatos szabályok azonban igen; ilyenek például a közforgalmú közlekedést ellátó autóbuszok műszaki paraméterei és biztonsági felszerelései. Az eltérő szabályozás megnehezíti az egyes közlekedési társaságok helyzetét, hiszen a nemzetközi forgalomra más felszereltségű járművekkel kell rendelkezniük, mint a belföldiben, és ez a határ menti regionális, interregionális vonalak, hálózatok (piaci indíttatású) kialakulásának sem kedvez.

A vasút területén az átjárhatóság néhol jelentős akadályokba ütközik. Már a pálya sem folytonos a kontinensen, egyes országokban a normál (1435 mm) nyomtáv helyett ennél szélesebbet alkalmaznak, illetve további jelentôs műszaki eltérés az országok vasúti hálózata között a villamosítási rendszer. A környezetvédelem előretörésével a villamos vontatás szerepe felértékelődik, ugyanakkor az egyes országok különböző módon építették ki a vasúti felsővezetéki hálózatot, így - amennyiben a vontatójárművek nem képesek haladni az eltérő hálózaton - mozdonycsere szükséges, ami szintén hátráltató tényező volt. A vasúti átjárhatóságot akadályozza továbbá az eltérően kiépített, vonatforgalmat biztosító rendszerek múködésének különbözősége. A vonatok biztonságos haladásához szükséges úgynevezett vonatbefolyásoló rendszerek ${ }^{12}$ más és más műszaki megoldása nem tette lehetôvé a nem megfelelő berendezéssel felszerelt vontatójárművek más országbeli közlekedését (1. sz. ábra), így emiatt is mozdonycsere vált szükségessé. Tovább nehezíti a helyzetet a vasúti közlekedés szabályainak teljes eltérése. Ezeket a szabályokat az egyes nemzeti vasúttársaságok a saját elveik alapján állapították meg (persze lehetnek egyezőségek), így például a jelzési rendszerek egyáltalán nem egyeznek meg úgy, mint a közút esetében. Az adminisztratív szabályok esetében már a XX. század első harmadában kialakult a törekvés az egységességre: a nemzetközi forgalmú vasúti kocsik

11 1980. ÉVI 3. TÖRVÉNYEREJÜ RENDELET AZ 1968. ÉVI NOVEMBER HÓ 8. NAPJÁN BÉCSBEN ALÁÍRÁSRA MEGNYITOTTT KÖZÚTI KÖZLEKEDÉSI EGYEZMÉNY KIHIRDETÉSÉRŐL

12 LÉVAI, 2019. 
közlekedésnek szabályait tartalmazó RIC ${ }^{13}$ egyezmény már 1922-ben életbe lépett és még napjainkban is érvényes, azonban csak a különböző személykocsikra vonatkozik, a mozdonyokra és az egyre elterjedő motorkocsikra nem. Ezt felismerve az európai vasúttársaságok az ERA ${ }^{14}$ vezetésével, az EU szakpolitikai támogatásával elkezdték kidolgozni azokat a technikai paramétereket, amelyek már mozdonyok és motorkocsik esetén is biztosítják az azonos szabványokat. A TSI-k ${ }^{15}$ vonatkoznak az infrastruktúrára, a gördülóállományra, a biztosítóberendezésekre, az informatikai alkalmazásokra, a vasútirányításra, az energiafelhasználásra és a zajkibocsátásra, valamint a segítséggel élők vasúti közlekedésére.

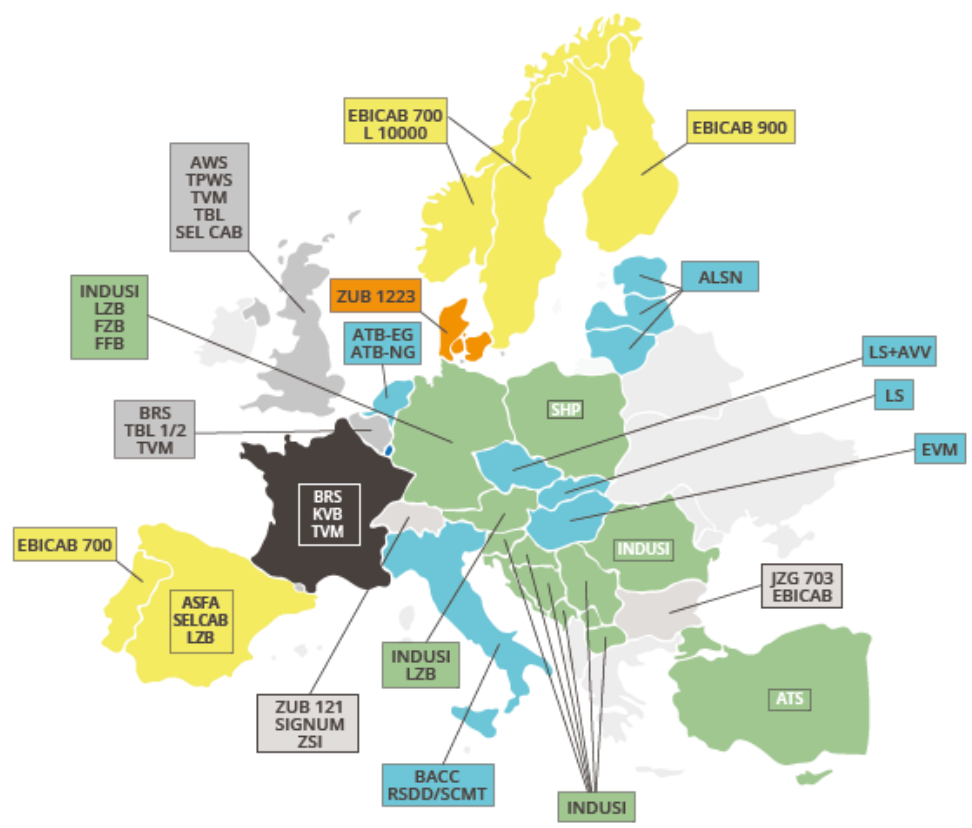

1. sz. ábra: Vonatbefolyásoló rendszerek Európában. ${ }^{16}$

\footnotetext{
${ }^{13}$ RIC - Regolamento Internazionale delle Carrozze - a vasúti kocsik nemzetközi használatának szabályai.

${ }^{14}$ ERA - European Railway Agency - az Európai Unió Vasúti Ügynöksége.

15 TSI - Technical Specifications for Interoperability - az interoperabilitást elősegítő műszaki specifikációk Forrás: https://www.era.europa.eu/activities/technical-specificationsinteroperability en

${ }^{16}$ ARATÓ, é. n. alapján saját szerkesztés.
} 


\subsection{Eltérő finanszírozási rendszerek}

A határon átnyúló közlekedés megszervezésének egyik sarkalatos kérdése az egyes járatok finanszírozása. Ennek oka az egyes országok eltérő finanszírozási rendszeréből fakad. Alapvetően kimondható, és a következő pontban bizonyítjuk, hogy a határ menti interregionális járatok a közszolgáltatás részeként tudnak csak közlekedni, ezért állami finanszírozásra szorulnak. A finanszírozás mértéke országonként különbözik, így az egyes országokban működő szolgáltatók nem kapnak egyenlő költségtérítést. Az országhatáron belüli közlekedés helyzete minden országban jól lehatároltnak mondható, az átjárás a határon azonban problémákat vet fel. Ezeken a rövid szakaszokon a járatok nem töltenek be közszolgáltatási funkciót, így nem alkalmazhatók rájuk az ezekért kapott állami támogatások, a közszolgáltatási ellentételezés. A vizsgálat tárgyát leginkább az képezi, hogy az utolsó belföldi megálló és az országhatár (határpont) közötti szakaszt ki finanszírozza.

Ugyancsak problémát jelentenek az egyes országok által alkalmazott eltérő tarifarendszerek. Az ennek alapját jelentő egységdíjtétel is országonként különbözik, így az egész útvonalra egységes díjtétel nem alkalmazható. Ehhez adódik még a kedvezményrendszerek különbözősége. Alapvetően minden ország tarifarendszerében megtalálhatók az egyes kedvezmények, amelyek elveikben még akár meg is egyezhetnek (például a szociálpolitikai menetdíj-támogatások), azonban az üzletpolitikai kedvezmények már nem esnek egybe és nem ugyanannak az utasrétegnek szólnak. A kedvezményekkel támogatottak köre is megegyezhet (például a tanulók), ugyanakkor az egységdíjtételből adódó különbségek a kedvezmények pénzbeli mértékét eltérően határozzák meg. A kedvezményrendszert alapvetően az állam és a szolgáltatók múködtetik. ${ }^{17} \mathrm{Az}$ egyes államok által meghatározott kedvezmények eltérései megnehezítik a határon átnyúló regionális közlekedés tarifáinak kialakítását, mely szintén akadálya a könnyú átjárhatóságnak.

\subsection{Eltérő nyelv}

Míg Nyugat-Európa egyes szomszédos államainak határ menti régióiban azonos nyelvet beszélnek (például németet) és ez hivatalos

17 TóTH-MAROS, 2017. 
nyelvnek is minősül, addig a Magyarország és szomszédai közötti forgalomlebonyolítás során a magyar nyelv nem használható közös üzemi nyelvként. ${ }^{18} \mathrm{Az}$ adatforgalmazás legalább kétnyelvü, de sok esetben a szomszéd ország nyelve a hivatalos (például Ausztria felé). Ez a körülmény szintén megnehezíti a határon átnyúló közlekedési szolgáltatások szervezését, mert megköveteli a szolgáltatóktól, hogy minden esetben idegen nyelvet is használjanak üzemi nyelvként. Ráadásul ahány szomszédos ország, annyi nyelv ismeretére lenne szükség. Természetesen egy szolgáltató nem minden országba közlekedtet regionális járatot, de például a vasút esetén a MÁV-START Zrt.-nek németül, szlovákul, ukránul, románul, szerbül, horvátul és szlovénül tudó munkavállalókra lenne szüksége a határ menti szolgáltatás szervezése érdekében.

\section{A REGIONÁLIS EGYÜTTMÜKÖDÉSEK HATÁSAI A KÖZLEKEDÉSRE}

Az európai integráció eredményeként erôsödő kapcsolatok hatásainak áttekintése kapcsán feltételezzük, hogy a szomszédos régiók együtt kívánnak működni egymással, és ez az együttműködés közlekedési igényeket generál.

\subsection{Társadalmi kapcsolatok}

Az egyes országok határai természetes határok (például folyók, hegyvonulatok), vagy politikai alkuk alapján mesterségesen lettek kijelölve. ${ }^{19}$ Ennek következtében kialakult társadalmi (rokoni, baráti stb.) kapcsolatok kerültek a határ két oldalára. Ezek a XX. század második felével ellentétben napjainkra a telekommunikációnak és a szabad határátlépésnek köszönhetőnek már nincsenek elzárva. Az emberi kapcsolatok a közlekedésre is hatással vannak: a család- és rokonlátogatások számának növekedése helyváltoztatási igényeket indukál, melyeket a közlekedés hivatott levezetni. Ezek a mikrokapcsolatok kiterjeszthetők a határon túli közösségek és az anyaország makrokapcsolatává, vagyis nem csak az egyes családok közlekednek a két ország között, hanem az egyes közösségek közötti kapcsolat is közlekedési igényeket szül.

\footnotetext{
18 Például a 170/1998 (X. 14.) KORM. RENDELET SZERINT.

19 NAGY, 2001.
} 


\subsection{Gazdasági kapcsolatok}

Minden régiónak megvannak a maga gazdasági kapcsolatai, amelynek része a szomszédos határ menti régióval kialakított gazdasági együttműködés is. Ennek mértéke régiónként eltérő lehet, ugyanakkor ez mindenféleképpen közlekedési (személy- és áruszállítási) szükségleteket generál. Az együttműködő vállalkozások egymás közötti árufuvarozási igényei, illetve az ezek közötti üzleti utazások hatással vannak a régiók közötti forgalom nagyságára.

A szolgáltatások piacán jelentkező különbségek is növelik a közlekedési igényt. A csak másik régióban elérhető, vagy ott olcsóbban megkapható szolgáltatások sokakat késztetnek arra, hogy útra keljenek és ezzel a két régió közötti forgalom nagyságát tovább növeljék.

Az egyes régiók eltérő gazdasági fejlettsége fellendítette a munkavállalással kapcsolatos - a kishatárforgalmon ${ }^{20}$ immár túlmutató utazásokat is. A határ menti ingázás ma már mindennapjaink része és ez lehet a határon átnyúló közforgalmú közlekedési kapcsolatok egyik alapja. Ugyanakkor látni kell, hogy ez a közlekedési igény általában egyirányú, így az oda-vissza forgalom ténylegesen megfeleltethetô a belföldi ingaforgalomnak.

\subsection{Oktatás és egészségügy}

A határ menti szomszédos régiókban a gazdaság mellett a közszolgáltatások, elsősorban az oktatás és az egészségügy színvonala is eltérő lehet. A határ menti nemzetiségi iskolák működése miatt számos esetben nincsenek nyelvi akadályok, így az iskolába járás is növeli a közlekedési igényt. Az egészségügyben elsősorban a szolgáltatások ár-érték aránya lehet meghatározó. A határon túliak által igénybe vehetô magyar közegészségügy, illetve bizonyos viszonylatokban a magánegészségügy alacsonyabb árai is arra ösztönzik a határ menti régiók lakosait, hogy ezeket a szolgáltatásokat a szomszédos régiókban vegyék igénybe.

\subsection{Turizmus}

A határok átjárhatósága fellendítheti a határ menti régiók közötti szabadidős vagy turizmus célú utazásokat is. Az attrakciók köre és a

${ }^{20}$ GRÓNÁS - SALLAI, 2005. 
desztinációmenedzsment régiónként eltérő lehet, a turizmus szektorban múködő vállalkozásoknak ugyanakkor az a céljuk, hogy a turistaszezont egész évre kiterjesszék (például egészség- és gyógyturizmus), továbbá eseményekhez kapcsolódó jelentős időszaki látogató- vagy turistaforgalmat generáljanak (például fesztiválok, kulturális programok). E szezonális látványosságok adott időszakban jelentősen megnövelhetik a közlekedési infrastruktúra és szolgáltatások igénybevételét, mely kapacitásgondokat eredményezhet. A határ menti régiók már említett, eltérő árszínvonalából ered a bevásárlóturizmus: ez a forgalmi áramlás általában egyirányú, de a gazdaság változásával az irány akár meg is változhat. ${ }^{21}$

\section{JÓ GYAKORLATOK A HATÁR MENTI KÖZLEKEDÉSI KAPCSOLATOKRA}

A CONPASS projekt ${ }^{22}$ keretében definiált határon átnyúló közforgalmú szolgáltatási fokozatok ${ }^{23}$ közül a koordinált és az integrált szolgáltatások tekinthetők jó gyakorlatnak. A koordináció létrejöhet a menetrendek, tarifák egyeztetésével, a szolgáltatók közötti, illetve hatóságokkal történő együttmúködés révén, valamint közös szabályok elfogadásával. Az integráció már a tervezés szintjén megvalósul, a határon átnyúló közlekedési viszonylatok az egyes belföldi rendszerek részét képezik, és azokba illeszkednek, ugyanakkor a jogszabályok harmonizációja nem feltétel.

\subsection{Menetrendi koordináció}

Alapvetően elmondható, hogy a menetrendek összekapcsolása a vasúti közlekedésben sarkalatos, mert a csatlakozási rendszerek különbözősége esetén a határon átmenő vonatok a semmiből a semmibe mennek, így az utasok számára nem jelentenek vonzó utazási alternatívát. Az autóbuszjáratok esetében általában a határ túloldalán található nagyobb település elérése a fontosabb, mint a csatlakozások elérése, ugyanakkor előfordulhat, hogy közel fekvő két nagyobb város között közlekedő autóbuszjáratok menetrendjét igazítani kell az ottanijáratok indulásához.

${ }^{21}$ SZÉKELY, 2013.

22 CONPASS: Better CONnections in European PASSenger Transport, EU 5th RTD Framework Programme. Forrás: https://trimis.ec.europa.eu/entityprint/node/2931

23 CONPASS, 2002. 
A menetrendek koordinációjával elérhető, hogy a határokhoz közeli átszállási rendszerek (együtt)múködjenek. Ennek alapja, hogy az egyes belföldi közforgalmú szolgáltatásokat kiterjesszék a határon túlra. Fontos azonban, hogy a határon átközlekedő regionális járatok a két ország belföldi menetrendi struktúrájához is igazodjanak, hogy megfelelő összeköttetést tudjanak teremteni. Korábban erre volt példa a magyar és a horvát vasutak Murakeresztúr - Varasd, Gyékényes - Kapronca, Magyarbóly Pélmonostor járatai.

A menetrendek összehangolása úgy is elérhető, hogy (vasútüzemi szempontból) közös határállomás üzemel, és a két ország vonatai eddig közlekednek. Ez a megoldás abban az esetben előnyös, ha a közös határállomás egyben vasúti csomópont is, ahol már csatlakozási rendszer múködik. Ilyenre példa osztrák/szlovák - cseh viszonylatban a Csehországban fekvő Břeclav állomás. Az ÖBB ${ }^{24}$ vonatai eddig közlekednek Ausztria, a $\mathrm{ZSSK}^{25}$ vonatai pedig Szlovákia felől, akárcsak a Čำ ${ }^{26}$ belföldi vonatai. Břeclav állomáson tehát három ország vasúti menetrendje találkozik. Az átszállási rendszer csak akkor múködik megfelelően, ha minden ország hasonló menetrendi szerkezetet használ: az ütemes menetrende ${ }^{27}$. A szerkezet megfelelő kialakításával elérhető, ${ }^{28}$ hogy mindhárom vasút esetében a csatlakozási pont éppen Břeclav állomásra essen, így mindhárom ország vonatai egy átszállási pontba érkeznek és onnan is indulnak.

\subsection{A tarifák koordinációja}

A határon átnyúló közösségi közlekedés megszervezésének legnagyobb kihívását a tarifa jelenti. ${ }^{29}$ A pályák rendelkezésre állnak, a menetrendek koordinációja a fent említett módon megoldható, ugyanakkor a nyújtott szolgáltatások finanszírozása nehézkes. Nem véletlenül áll ez a kérdés a határon átnyúló közforgalmú közlekedési rendszerek kutatásának középpontjában. Az egységes tarifák kialakíthatóságának díjszabási nehézségeit feljebb bemutattuk, ugyanakkor számos jó példát találunk

\footnotetext{
${ }^{24}$ ÖBB - Österreichische Bundesbahnen - Osztrák Szövetségi Vasutak.

25 ZSSK - Železnična spoločnost’ Slovensko a.s. - Szlovákiai Vasúttársaság Rt.

${ }^{26}$ ČD - Ceské dráby - Cseh Vasutak Rt.

27 Ács, 2009.

${ }^{28}$ WELS, 2006.

${ }^{29}$ BERÉNYI - SISKA, 2020.
} 
határon átnyúló díjszabásra, illetve közlekedési szövetségekre egységes díjszabással. Ezek hátterében az áll, hogy a határ menti régiók (és más közigazgatási egységek, akár az államok) felismerték, hogy vonzó határon átnyúló közforgalmú közlekedés csak egységes tarifával hozható létre, így együttmúködésüknek és megállapodásaiknak köszönhetően összehangolt díjszabási rendszerek jöttek létre. Előzményként említhető az eurorégiók megalakulása, ${ }^{30}$ amelyekben a részt vevő régiók elsődleges célja a határtérségek elzárkózásának elbontása volt - ennek részeként pedig a határok átjárhatósága is.

$\mathrm{Az}$ egységes tarifa kialakítása során a viteldijjendszerek összehangolását a különböző jogszabályi környezet és a másféle díjképzési módszertan miatt a felek nem szokták alkalmazni, ezért leginkább új, de egységes viteldíjszabályokat alkotnak. Ebben az esetben adott ország közszolgáltatási felelősének döntési jogköre, hogy valamely régióban a belföldi és a közlekedési szövetség dijszabása is alkalmazható-e, vagy belföldi forgalomban melyik díjszabás kizárólagosságát kell biztosítani.

\subsection{A szolgáltatók együttmüködése}

A legteljesebb együttműködési forma a közlekedési szövetségek létrehozása. ${ }^{31}$ A közlekedési szövetségekben a felek együttmúködése az alábbi területekre terjed ki: ${ }^{32}$

- a hálózat összehangolása;

- menetrendek összehangolása;

- egységes jegy- és viteldíjrendszer múködtetése;

- egységes utastájékoztatási rendszer üzemeltetése;

- az átszállási pontok integrált kialakítása $\left(\mathrm{P}+\mathrm{R}^{33}, \mathrm{~B}+\mathrm{R}^{34}\right.$ parkolók építése).

Az együttmúködésekkel elkerülhető a kabotázs, amennyiben adott országban a személyszállítási piacon még nem történt piacnyitás. A szolgáltatókon kívül az ellátásért felelős szervek együttmúködése akkor szükséges, ha a finanszírozás a szolgáltatások bevételeiből nem oldható meg.

\footnotetext{
${ }^{30} \mathrm{Az}$ eurorégiók az Európa Tanács kezdeményezésére létrejövő határon átnyúló együttmúködések két vagy több európai országban található térség között (Bagaméri, 2010).

31 MUNKÁCSY - JÁSZBERÉNYI, 2018.

32 KTI, 2019.

33 Park and Ride.

${ }^{34}$ Bike and Ride.
} 


\subsection{Együttmüködés a hatóságokkal}

A határ menti régiók együttműködése nemcsak uniós viszonylatban képzelhető el, hanem olyan területeken is, ahol még határellenőrzés szükséges a szomszédos országba való utazáshoz. Ebben az esetben a szolgáltatások attraktivitása a vizsgálat lefolytatásától is függ. A fent bemutatott ütemes menetrendi struktúra az átszállási rendszerek megfelelő működéséhez megköveteli a menetrendek betartását, így nem szerencsés, ha a határállomási tartózkodási idő hosszának hullámzása bizonytalanná teszi a járat menetidejét. Ennek megoldása lehet az együttműködés kialakítása a határellenőrzést végző szervekkel. Az együttmúködés célja, hogy a határra érkező járatok vizsgálata lehetőleg azonos idő alatt történjen meg. Ehhez alapfeltétel, hogy a felek megegyezzenek a kölcsönösen elfogadható tartózkodási időben. Meg kell említeni, hogy a két fél érdeke ebben a kérdésben eltérhet, ${ }^{35}$ szükséges a megfelelő kompromisszum megtalálása.

További fontos körülmény, hogy a vizsgálat időben meg tudjon kezdődni. Erre megoldásként javasolható a járatok érkezési idejének előjelzése a határállomásra, hogy a hatóságok készülni tudjanak az ellenôrzésre. Közúti közlekedés esetén bizonyos időszakokban előfordulhat az átkelő zsúfoltsága. Ez a körülmény is jelentősen befolyásolhatja a menetrend betartását, ezért célszerú az autóbuszok folyamatos haladását biztosítani. Ennek egyik megoldása lehet, ha nem a legnagyobb forgalmú határátkelőket használják. Elképzelhető, hogy így nem a leggyorsabb eljutási idő adódik, azonban a hosszabb, de megbízhatóan tartható menetidő kedvezőbb az utasok számára, mint a rövidebb, de sok esetben nem tartható menetrend.

A vizsgálat idejét ugyancsak meghatározza a járaton utazók száma. Lehetnek olyan, kiugróan magas utasforgalmú időszakok, amikor a járat utasszáma többszöröse az általában megszokottnak. Ebben az esetben javasolható az utasszám előrejelzése a hatóságok felé, akik a megállapodásban vállalják, hogy ennek megfelelő ellenőrzőlétszámot biztosítanak.

35 LÉVAI, 2020. 


\subsection{Közös szabályok alkalmazása}

Elsősorban említhetjük, hogy bármilyen közforgalmú közlekedési együttműködés megteremtéséhez nemzetközi szerződés megkötése szükséges (például az egyes államok megállapodása a határon átmenő vasúti forgalomról). Ebben a szerződésben szükséges rögzíteni azokat a közös szabályokat, amelyek az együttmúködés alapjait jelentik.

Ugyancsak közös szabályozásnak tekinthetô, ha a felek közösen alkalmaznak már létező szabályokat (például a vasutak tekintetében a RIC megállapodást vagy a TAP ${ }^{36}$-TSI keretrendszert). A legegyszerúbb közös szabályozás a határállomásig történő közlekedés megengedése. A vasutak tekintetében is a RIC vagy a TSI alkalmazása mellőzhető, ha adott vonat csak a belépő határállomásig közlekedik.

\subsection{Példák Európából}

A menetrendi koordinációra - a már említett cseh, szlovák, osztrák együttmúködés mellett - jó példa a lengyelországi Kostrzynn nad Odra, ahol a lengyel és a német vasút alakított ki hasonló rendszert, valamint a németországi Kebl, ahol egy magánvasúttársaság közlekedik a német és a francia belföldi hálózat között, illeszkedve mindkét belföldi rendszerhez.

A tarifák koordinációja valósul meg a németországi Drezda és a csehországi Ústí nad Labem között használható Elbe-Label Ticket esetében. A közös jegy a két ország területi egységeinek átjárhatóságát segíti elő. Hasonló elgondolás alapján múködik az EuroNeiss Ticket rendszer, amely a német - cseh - lengyel hármashatáron átnyúló egységes tarifarendszer (és menetrendi koordináció) példája.

A szolgáltatók együttmúködésére, vagyis a közlekedési szövetségekre számos megfontolásra érdemes példa sorolható. A témában készült kutatási jelentés ${ }^{37}$ a TriRegio (Franciaország, Németország, Svájc) példáján keresztül az egyes országokban múködő közlekedési szövetségek nemzetközi szövetségét, a VRN ${ }^{38}$ (Németország, Franciaország) példáján keresztül egy nemzeti közlekedési szövetség átnyúlását egy másik országba, a VVT ${ }^{39}$ (Ausztria, Olaszország) példáján keresztül a közlekedési szövetség két

\footnotetext{
36 TAP - Telematics Application for Passenger service.

${ }^{37}$ KTI, 2019.

38 VRN - Verkehrsverbund Rhein-Neckar.

${ }^{39}$ VVT - Verkebrsverbund Tirol.
} 
régiója közé ékelődő másik ország közlekedési szövetségére alapozott összeköttetést mutatja be.

$\mathrm{Az}$ intermodalitás kapcsán a Peripheral Access projektben ${ }^{40}$ a projektpartnerek bemutatták azokat az európai példákat ${ }^{41}$, amelyekben a módok közötti kapcsolat jelentős szerepet játszik a közlekedésben, elsősorban az igényvezérelt és a közforgalmú közlekedés közötti átszállás kapcsán.

\section{MAGYARORSZÁGI LEHETŐSÉGEK A HATÁR MENTI EGYÜTTMÜKÖDÉSRE}

A hazai határ menti régiók konkrét együttmúködési lehetőségeit az egyes régiók átjárhatóságát vizsgáló korábbi tanulmányok már feltárták, ${ }^{42}$ az alábbiakban ezért az egyes közlekedési módok lehetséges szerepét vizsgáljuk a határon átnyúló közlekedésben. Bár jelen cikk a közforgalmú közlekedési összeköttetések fejlesztési lehetôségeit vizsgálja (és ezért az alábbiakban az autóbusz- és a vasúti közlekedés kapcsán fogalmaz meg javaslatokat), érdemes kiemelni, hogy több projektben ${ }^{43}$ is foglalkoztak a határ menti térségekben a kerékpározás kérdésével, amelynek szerepét a nem közúti kapcsolatok (erdészeti, mezőgazdasági utak) kiaknázása is erősítheti. ${ }^{44}$

40 Peripheral Access, Interreg Central Europe, 2017-2020. Hazai projektpartner: KTI. https://www.interreg-central.eu/Content.Node/Peripheral-Access.html

${ }^{41}$ IR CE, 2018.

${ }^{42}$ KTI, 2011, 2012, 2014, 2019.

43 Például:

- VELOREGIO: Közös határon átnyúló kínálat fejlesztése és megvalósítása az osztrákmagyar határtérség kerékpáros régióiban, INTERREG Ausztria-Magyarország Együttműködési Program, 2018-2020. Hazai projektpartnerek: Vas Megyei Önkormányzati Hivatal, Kőszeg Város Önkormányzata, Savaria Turizmus Nonprofit Kft. Forrás: https://www.interreg-athu.eu/hu/veloregio/

- TransHUSK Plus: A fenntartható közlekedés fejlesztése az információszolgáltatás és az intermodalitás javításával a magyar-szlovák határtérségben, INTERREG Magyarország-Szlovákia Együttmúködési Program, 2014-2015. Hazai projektpartnerek: KTI, Nyugat-Pannon Terület- és Gazdaságifejlesztési Szolgáltató Kft. Forrás: https://www.kti.hu/projektek/kiemelt-nemzetkozi-projektjek/transhusk-plus-projekt/

- Danube Cycle Plans: Policies, plans and promotion for more people cycling in the Danube region, INTERREG Danube Transnational Programme, 2020-2022. Hazai projektpartner: KTI. Forrás: http://www.interreg-danube.eu/approvedprojects/danube-cycle-plans

${ }^{44}$ MUNKÁCSY ÉS MTSAI., 2020. 
Továbbá érdemes felvetni a vízi közlekedési összeköttetések bővítését (ideértve a kompokat) is.

\subsection{Autóbusz-közlekedés}

A határon átnyúló közlekedés szempontjából az autóbusz-közlekedés viszonylag egyszerűen (például bármely közúti határátkelőn) alkalmazható. Mivel az ütemes menetrend a közforgalmú regionális autóbuszközlekedésben sem hazánkban, sem Ausztria kivételével a környező országokban nem terjedt el, a menetrendi koordináció napjainkban kívánatos lenne, de nem szükségszerü. Különösen igaz ez, ha a járatok az ingaforgalom utasait szállítják: ezekben az esetekben elegendő a fô célként meghatározott célpont időrendjéhez igazítani a menetrendet (például üzemek, iskolák, egészségügyi intézmények stb.). Ilyen igények majdnem minden határ menti régióban jelentkeznek. A járatok közlekedését alapvetően három modell szerint lehet szervezni ${ }^{45}$ (2. sz. ábra):

- shuttle-rendszer (csak a két határ menti település között);

- átlapolt szolgáltatás (a járatok meghosszabbítása a határon túli első településig);

- hálózatba kötés (a járatok a két országbeli csatlakozási pontok között közlekednek, a belföldi hálózat részét alkotva).

${ }^{45}$ KTI, 2019. 


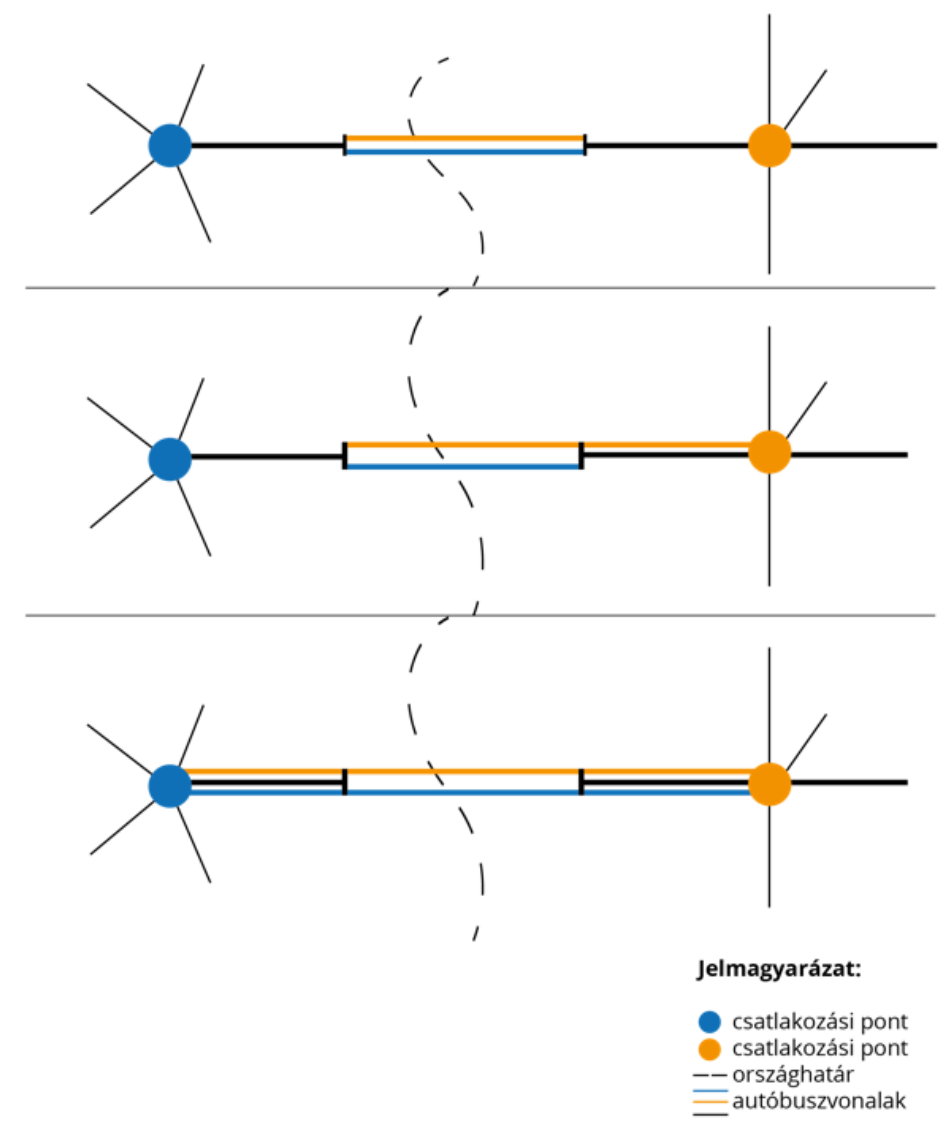

2. számú ábra: Határon átnyúló buszjáratok modelljei ${ }^{46}$

\subsection{Vasúti közlekedés}

Vasúti határátmenetből jelentôsen kevesebb van, és a vasútvonalak nem érnek el minden jelentős vonzásközpontot. A vasúti alágazat már jóval kiterjedtebben használja az ütemes menetrendet, mely az átszállási rendszerek megfelelő működésének alapja. Ausztria és Szlovákia irányába ilyen alapon történik a vonatközlekedés szervezése, a határon átmenő regionális vonatok is ehhez alkalmazkodnak. Ugyanakkor Szlovákia irányába csak a lehetséges átmenetek kevesebb, mint felében van személyközlekedés,

${ }^{46}$ KTI, 2019 alapján saját szerkesztés. 
regionális vonatok pedig csak a rajkai átmenetben közlekednek. Többi szomszédunk irányába nincs ütemes menetrend a határátmenetben, és regionális kapcsolatokról csak Románia felé beszélhetünk. Ugyanakkor a vasúti határátmenetek rendelkezésre állnak, illetve kis beruházásokkal a volt és ma már nem üzemelő határátmenetekben is felvehető a vasúti forgalom, mely sok esetben kiválthatja a közúti forgalom egy részét.

A vasúti kishatárforgalomban a gazdaságos üzemelés alapja az optimális menetrend, valamint jármú- és személyzetfordulók. Javasolható az ütemes menetrend kiterjesztése nemzetközi regionális forgalomba az alábbiak szerint:

- egységes szimmetriatengely megválasztása (az Európában elfogadott 14:00 órás szimmetriatengely használata);

- a vonatok illeszkedjenek a két ország csatlakozási rendszereihez;

- az így optimalizált menetrend alapján a fordulók kialakítása átjárással a szomszéd országba (alaptételként fogalmazhatjuk meg, hogy az a jármú és személyzet járjon át a másik országba, amelynek a határállomási fordulójába belefér);

- az így közlekedő vonatokat mindkét állam fogadja be a közszolgáltatás részeként;

- a küldő állam vasúttársasága a nemzetközi vasúti megállapodások alapján részére járó díjaktól tekintsen el (ezt kapja meg kompenzációként saját államától).

A vasúti közlekedés (közúthoz viszonyítva) környezetet kevésbé terhelő jellemzői miatt javasolható a regionális határon átnyúló forgalmak erôsítéséhez a létező, de ma nem használt, illetve az alacsony beruházási költséggel megépíthetô, korábban üzemelő vonalak újranyitása. Az így kialakítható közvetlen regionális összeköttetés olyan városok és régióik között élénkítheti a társadalmi és gazdasági kapcsolatokat, mint Miskolc és Kassa, Debrecen és Nagyvárad, Szeged és Szabadka, Pécs és Eszék.

\section{KONKLÚZIÓ}

A XXI. század mobilitása már nem áll meg az országhatároknál. Az Európai Unió kínálta mozgási szabadság elindította a határt átszelő közlekedési folyamatokat. Az országhatárok fizikai lebomlása lehetővé tette, hogy a határok szabadon átjárhatók legyenek, ez pedig a nemzetközi helyváltoztatási igények jelentős növekedését eredményezte. Erre az igényre már a közforgalmú közlekedési rendszernek is reagálnia kellett. Nyugat- 
Európában a XX. század végén, a XXI. század elején létre is jöttek azok a megoldások, amelyek elősegítették a határ menti regionális kapcsolatok kialakítását. Magyarország esetében az országhatár még napjainkban is sok esetben sorompóként szolgál a közforgalmú közlekedés előtt, így az országhatáron áthaladó regionális közlekedési járatok száma alacsony.

A 2010-es években több kutatás is javaslatot tett a határ menti közforgalmú közlekedés fejlesztésére. Eredményeiket felhasználva jelen cikkben bemutattuk azokat a lehetőségeket, amelyek hazánk számára is adva vannak, hogy megfelelő színvonalú határon átnyúló közforgalmú közlekedési rendszert alakítson ki, együttmúködésben a szomszédos országokkal. Az egyes konkrét fejlesztési javaslatokat az adott projekteket lezáró tanulmányok tartalmazzák, melyekből az elmúlt időszakban néhány meg is valósult, például a GYSEV Zrt. tett konkrét intézkedéseket a határon átnyúló vasúti közlekedés fejlesztése érdekében. Mi ebben a cikkben az elméleti kérdéseket tekintettük át. Cikkünk első részében bemutattuk és vizsgáltuk azokat a sorompóhatásokat, amelyek nehezítik a határon átnyúló közlekedés szervezését, majd a regionális együttműködés közlekedést érintő hatásaival foglalkoztunk. E két terület problémáinak megoldására európai jó gyakorlatokat mutattunk be. Kutatásunk alapján megfogalmaztuk a magyarországi határon átnyúló regionális közlekedés lehetőségeit az autóbusszal végzett és a vasúti személyszállításban.

Vizsgálatunk alapján az alábbi következtetéseket és megállapításokat tesszük:

- a határon átnyúló regionális közlekedés kialakítása elsősorban a közszolgáltatás részének tekinthető;

- megvalósításának az ellátásért felelős szervezetek együttmúködésén kell alapulnia;

- a finanszírozás kérdését is ennek megfelelően kell kezelni;

- a határon átnyúló közforgalmú közlekedés képes a helyi és a távolsági érdekek kiszolgálására, erről a döntést az ellátásért felelősnek kell meghoznia;

- ha a határon átnyúló szolgáltatást a belföldi hálózatok összekötésére használják, javasolható az ütemes menetrendi szerkezet kialakítása, lehetôleg 14:00 órás szimmetriatengely megválasztásával;

- a közlekedési szolgáltatók egymás közötti elszámolását adott esetben állami szerepvállalással kell kisegíteni;

- a megfelelő kerékpárút-hálózat kialakítása és a kerékpárszállítás lehetôvé tétele a határon átmenő járatokon jelentősen elősegíti a 
nemzetközi kerékpáros turizmus és a regionális kapcsolatok fejlődését.

A kutatás felvetését, miszerint a határon átnyúló közforgalmú közlekedés erôsíti és elősegíti a szomszédos régiók kapcsolatát, európai jó példákkal és kutatási eredményeinkkel támasztottuk alá. Ugyanakkor megállapításaink elméleti jellegúek, a gyakorlati alkalmazás a diplomácia és a közlekedésfejlesztés szakmai feladata. A fentiekből további kutatási irányok is kirajzolódnak: részben külügyi témájú vizsgálatok (például a határ menti közlekedési célú együttmúködések eltérő diplomáciai stratégiáinak elemzése, a változó külügyi kapcsolatok hatása a határ menti közlekedésfejlesztésre), részben pedig közlekedési kutatások (például a határ két oldalán az eltérô mobilitási szokások feltárása).

\section{KÖSZÖNETNYILVÁNÍTÁS}

Jelen publikáció az Innovációs és Technológiai Minisztérium Kooperatív Doktori Program Doktori Hallgatói Ösztöndíj Programjának a Nemzeti Kutatási, Fejlesztési és Innovációs Alapból finanszírozott szakmai támogatásával készült.

\section{FELHASZNÁLT IRODALOM}

170/1998. (X. 14.) KORM. RENDELET a Magyar Köztársaság Kormánya és Románia Kormánya között Budapesten, 1997. március 12-én aláirt, az államhatáron keresztül megvalósuló vasúti határforgalom lebonyolításáról szóló Egyezmény kihirdetéséről.

ÁCs BALÁZs (2009): Integrált ütemes menetrend bevezetésének lehetöség az autóbuszkǫ̈llekedésben; In: Füredi Mihály (szerk.): KTI Évkönyv 2008, KTI Közlekedéstudományi Intézet Nonprofit Kft., Budapest.

ArATó KÁroly (é. n.): Vasúti rendszertechnikai ismeretek; Széchenyi István

Egyetem, Győr.

Elérhető:

https://fk.sze.hu/downloadmanager/download/nohtml/1/id/99/

(Letöltve: 2017. 08. 28.)

BAgAMÉRI DÁNIEL (2010): Az osztrák-magyar határon átnyúló regionális együttmüködésröl; Nemzet és Biztonság, 3:4, pp. 18-26.

BERÉNYI JÁNOS - SISKA MIKLÓS (2020): Határon átnyúló közlekedési sqövetség kialakitásának tarifális kérdései; In: Munkácsy András - Jászberényi Melinda: Utazás a tudományban 2020. Mobilitás a jövőben. Budapesti 
Corvinus Egyetem, 2020. február 21. Konferenciakötet. Budapest, pp. 14-15.

CONPASS (2002): Final Publishable Report: Better Connections in European Passenger Transport.

EU (2012): Az Európai Unió alapjogi chartája (2012/C 326/02). Letöltés helye: https://eur-lex.europa.eu/legal-

content/HU/TXT/PDF/?uri=CELEX:12012P/TXT\&from $=\mathrm{HU}$

(Letöltve: 2021. 10. 04.)

EU (é. n.): Határok nélküli Európa. Elérhető: https://europa.eu/europeanunion/about-eu/history/1990-1999 hu (Megtekintve: 2021. 11. 02.)

FEJES ZSUZSANNA (2010): A határon átnyúló együttmüködések, jogi és közigazgatási feltételei különös tekintettel a magyar határrégiókra; $\mathrm{PhD}$ értekezés, Szegedi Tudományegyetem Állam- és Jogtudományi Doktori Iskola, Szeged.

GRÓNÁS JÓZSEF - SALLAI JÁNOS: Kishatárforgalom története és jövöje az EU-ban; Hadtudomány, 15:2, Letöltés helye: https://www.mhtt.eu/hadtudomany/2005/2/2005 2 11.html (Letöltve: 2021. 10. 08.)

KOVÁCS ElŐD - SipOS NORBERT (2020): Mobilitás a határmenti régiókban Ausz̨tria; Pécsi Munkajogi Közlemények, 13:különszám, pp. 14-31.

KRUPPA ÉVA (2003): Régiók a határon: határmenti együttmüködés az Európai Unióban és Közép-Európában; PhD értekezés, Budapesti Közgazdaságtudományi és Államigazgatási Egyetem Nemzetközi Kapcsolatok Doktori Iskola, Budapest.

KTI (2011): Határon átnyúló közlekedési koncepció - határon átnyúló mobilitás Burgenland - Magyarorsæág; GreMo Pannonia L00025 Projekt (témaszám: 2121-024-1-1), Budapest.

KTI (2012): A batáron átnyúló közösségi közlekedés fejlesztése a Szabadka - Szeged régióban; tanulmány, (témaszám: 2121-038-1-1), Szeged.

KTI (2014): A mobilitás elösegitése a magyar-szlovák határ mentén a tömegközlekedés fejlesztése révén; Záró tanulmány (HUSK/1101/2.3.2/0335); Budapest.

KTI (2019): Sustainable Mobility and Accessibility for Regional Transport in Burgenland - West-Hungary; SMART Pannonia projekt (ATHU017); tanulmány, Budapest.

LÉvai Zsolt (2019): Közlekedésbiztonság; Dialóg Campus Kiadó, Budapest.

LÉVAI ZSOLT (2020): A határvédelmi követelményeknek való megfelelés vizsgálata és továbbfejlesztésének lehetôségei a vasúti határállomásokon I. résæ: Altalános határvédelmi követelmények és a vasúti határállomások üzemi folyamatai; Katonai 
Logisztika, 28:3, pp. 114-140. DOI azonosító: https://doi.org/10.30583/2020.3.114

MUNKÁCSY ANDRÁs - JÁSZBERÉNYI MELINDA (2018): A közúti közllekedés, a városi mobilitás és a turizmus; In: Jászberényi Melinda - Munkácsy András: Közlekedés, mobilitás, turizmus, Akadémiai Kiadó, Budapest.

MunKÁCSY ANDRÁs - VIRÁG Álmos - CSENDES BÁLINT (2020): Kerékpározás az erdészeti utakon: gondolatok egy kerékpáros turisztikai útvonalak értékelésére szolgáló módszerer elsô alkalmazása nyomán; Útügyi Lapok 8:13, pp. 61-76. DOI azonosító: https://doi.org/10.36246/UL.2020.1.05

NAgY TAMÁs (2001): Trianon és a magyar vasút; In: Magyarország és Európa 1919-1939 (14) pp. 149-166.

OsZTER VILMOS (2020): Cross-border public transport options in Central Europe: service gaps and planned solutions from the CONNECT2CE project, In: Horvath Balázs - Horváth Gábor (szerk.): X. Közlekedéstudományi Konferencia 2020, Győr (tanulmánykötet), Széchenyi István Egyetem Közlekedési Tanszék - Közlekedéstudományi Egyesület, Győr, paper 31.

REICHENBERGER, ANNA - RUBINI, LUCIO - MAZZARINO, MARCO - VirÁG Álmos (szerk.) (2018): EU-wide status quo analysis, A good practice analysis. Interreg Central Europe Peripheral Access project. Letöltés helye: https://www.interreg-central.eu/Content.Node/PA-EUwide-analysisfinal-WP1.pdf (Letöltve: 2021. 10. 04.)

SZÉKELY ANDREA (2013): A turizmus térszerkezeti hatása a határrégiókban; Jelenkori társadalmi és gazdasági folyamatok, 8:1-2, pp. 83-87.

TÓTH-MARos DÁNIEL (2016): Vasúti személyszállitási szerzódéstan; MÁV Szolgáltató Központ Zrt. Baross Gábor Oktatási Központ, Budapest.

Wels, PHILIPP (2006): Integrierter Stundentakt für das südöstliche Mitteleuropa Eine Strategie für den grenzüberschreitenden Personenverkebr; Eisenbahntechnische Rundschau, 2006:1-2, pp. 23-30. 